\title{
Effects of Biochar Addition on Vermicomposting of Food Industry Sewage Sludge
}

\author{
Jakub Świątek', Tadeáš Spitzer², Anna Grobelak ${ }^{*}$, Małgorzata Kacprzak' \\ 1 Częstochowa University of Technology, Faculty of Infrastructure and Environment, Poland \\ 2 Universita Tomáše Bati in Zlín, Fakulta Technologická, Institute of Environmental Protection Engineering, \\ Czech Republic \\ * Corresponding author's e-mail: agrobelak@is.pcz.czest.pl
}

\begin{abstract}
Sewage sludge (SS) is a byproduct of wastewater treatment which is commonly used as fertilizer in the world. However, due to the possible contamination with heavy metals, xenobiotics and fecal pathogens, its application on fields is not so common in Poland. A safer alternative for agricultural use is the SS produced by food industry in small ,inhouse" wastewater treatment plants, as substances that are used in its production are usually less harmful. As pretreatment of industrial wastewater is required before dumping the wastewater into common stream, the SS is an abundant byproduct that needs to be managed in an environmentally friendly and cost effective manner. Because the water content in SS is usually high, the dosage and logistics are problematic and thus we propose converting the sewage sludge into solid granular fertilizer in the vermicomposting process. Not only are the weight and volume of product decreased as a result, but also the nutrients such as N, P, and K become concentrated and made more accessible for plants. The SS is also further stabilized and less prone to produce odors and becoming putrid. The aim of this study was the in-depth analysis of the SS process vermicomposting with biochar. The SS was acquired from a local soft drink factory wastewater treatment plant. The batches of SS were inoculated with $20 \%$ mature vermicompost and E. fetida worms. Instead of typical bulking agents (like woodchips or straw) powdered biochar was used in the concentrations of 5, 10 and $15 \%$ as it exhibits beneficial influence on the process and increase the value of the final product.
\end{abstract}

Keywords: vermicomposting, biochar, sewage sludge, soil amendment

\section{INTRODUCTION}

The biological treatment of wastewater results in the generation of various byproducts that can be further processed to make them more inert and less dangerous to release in the environment. The greatest issue is proper management of sewage sludge (SS) that is produced in abundance in most of the Polish sewage treatment stations, as the active sludge method is probably one of the most popular technologies, both in municipal and industrial installations. The resulting sewage sludge is rich in the substances that can be used in agriculture but usually the high content of hazardous chemicals and microbial pathogens rule this option out [Mininni and Santori 1987; Leila et al. 2017; Raheem et al. 2018]. In order to reduce the amount of the
$\mathrm{SS}$, it is usually processed further to obtain usable biogas used on site to produce heat and/or generate electricity. However, this only reduces the volume and amount of SS and remainder still needs to be disposed of, for example by mechanically dewatering and drying to achieve a combustible pellet [Kijo-Kleczkowska et al. 2012].

Sewage sludge that would not contain harmful substances could, in theory, provide cheap end excellent substrate to produce fertilizers as it contains mostly concentrated nutrients from the wastewater stream [Day and Ludeke 1993]. However, the storage, transport and dosage may pose problems as sludge with high water content is bulky and prone to decay. Additionally, as with many other similar fertilizers, there is a danger of over fertilization that would burn the crop. Those problems could be offset by additional processing 
step of vermicomposting that would lead to the production of stable fertilizer that can be easily transported, stored and dosed [Munroe 2007]. A small-scale processing plant would complement the industrial wastewater treatment operations and, in theory, could offset the running costs by producing a valuable fertilizer instead of problematic byproducts [Vigueros and Ramírez Camperos 2002; Ludibeth et al. 2012].

The greatest issue to overcome in this approach is the high water content of the SS. Vermicomposting species of worms can usually cope with higher water content, but such substrate usually would became anaerobic and easily spoil. SS can be processed by mechanical dewatering, which would result in substrate of more appropriate water content, however still prone to becoming putrid. The usual solution to overcome this issue would be to mix the sludge with some kind of bulking material. Typically, straw or woodchips would be used in the dose depending on the initial qualities of the substrate [Munroe 2007]. This generates new costs, as bulking materials have to be purchased, transported and mixed with the substrate. However, in the end those bulking materials have no additional beneficial influence on the final product [Suthar 2009].

During early work on the subject of using biochar in vermicomposting, we carried out an easy experiment to determine if a batch of newly bought biochar had any negative effect on the worms. $20 \%(\mathrm{w} / \mathrm{w})$ dose of powdered biochar was added to a mix of vermicompost and coffee grounds had a positive effect on stabilizing the moisture content and the population of worms seemed to thrive despite no bulking materials added. The mix stayed loose and well aerated and this sparked an idea for a larger scale experiment to further analyze the effect in a more controlled and organized way.

The benefits of biochar are widely recognized in the science community and thus the biochar was used along the vermicomposting before. However, after analyzing the research papers on the subject we concluded it is likely that it was never used as a replacement of bulking material in vermicomposting, but only as an addition to improve the qualities of the final product. The research of Malińska et al. (2016), who used biochar produced by pyrolysis of the sewage sludge itself, is the closest. The research concluded that the addition of biochar is beneficial to the process. In other studies, biochar was added to the already produced vermicompost and in all cases it improved the qualities of the fertilizer [Malińska et al. 2016]. Researchers report better moisture retention in the amended soil and improved overall growth. The studies utilizing biochar as the only additive to the soil also confirm its positive influence on growth in concentrations as low as $1 \%$ [Meller Harel et al. 2012]. Both vermicompost and biochar were thoroughly studied and their qualities are well-known in the science community [Wang et al. 2018,Medyńska-Juraszek 2016].

In our opinion, the proposed approach has many benefits. The biochar used in our research is an effect of energy generation from forestry waste, so it is a useful byproduct rather than a purposefully produced substrate. In a powdered form, it can be stored easier than other bulking materials, also it is stable so it will not spoil over time. After its work as a bulking material is done, it stays in the product to became an valuable addition to soil, both as a moisture retainer and also as a sorbent that prolongs the presence of nutrients and makes them less prone to washout due to rainfall [Doan et al. 2015]. Each grain of biochar is also a great environment for a microbial population to grow and survive [Doan et al. 2014] and in combination with the qualities of vermicompost, it can counteract pathogens [Mu et al. 2017]. Even if the cost of using biochar as a bulking material is higher, the benefits it presents may justify the added expense.

The aim of this study was to test the hypothesis that biochar can replace bulking material in vermicomposting of sewage sludge. A basic experiment was carried out to test the effects on the final product and the change of E. fetida worms biomass.

\section{MATERIALS AND METHODS}

\section{Substrates}

The sewage sludge was collected from a local soft drink company in house wastewater treatment plant. The sample dried in $105^{\circ} \mathrm{C}$ indicated the dry mass content $\sim 12.93 \%$ and $\mathrm{pH}$ checked in water and $\mathrm{KCl}$ solution was $\sim 7.6$ and $\sim 6.8$, respectively. Microbiology assay on Wilson Blair (Merck) and Chromocult Coliform (Merck) agars indicated that sludge was free from E. coli and Salmonella. ICP-AES detected no harmful elements and a promising content of biogenic elements.

The biochar was obtained from a Polish company Fluid and was produced by pyrolysis of waste woodchips. Manufacturer's in-house 
testing results indicate the element composition of the batch as $\mathrm{C}: \sim 92.57 \%, \mathrm{H}: \sim 0.65 \%, \mathrm{~S}: \sim 0.07 \%$. The analysis with ICP-AES determined the biochar does not contain any harmful elements.

Inoculum was the material from the bins used to culture the worms between experiments and consisted of almost pure vermicompost. The standard feed for the worms in those bins are coffee grounds and tea leaves collected from researchers' households. E. fetida worms were obtained from a specialized vendor.

\section{Worm cultures}

In order to test biochar as a possible bedding material, 8 different mixes of substrates with various amounts of feed, inoculum and biochar were prepared. The contents of the mix and its role in the study are explained in the table below. Substrates were put in approximately 31 opaque containers with fitting lids. After thoroughly mixing, water was added to trials appearing as too dry and finally the contents resembled moisture of wrought out sponge. It was necessary to rise the $\mathrm{pH}$ of trials $1 \mathrm{~A}, 1 \mathrm{~B}$ and $3 \mathrm{~A}, 3 \mathrm{~B}$ as acidity visibly irritated the worms, so $2 \mathrm{~g}$ of $\mathrm{CaCO}_{3}$ and $1 \mathrm{~g}$ $\mathrm{CaO}$ was mixed in and left for night to settle after the rise of temperature. Soon, $10 \mathrm{~g}$ of mature E. fetida worms were added to the containers and lids were put on, ensuring that small $(3 \mathrm{~cm}$ in diameter) vent holes were unobstructed. The containers were left on bench in a shaded lab away from direct sunlight and throughout the trial, the ambient temperature stayed between $19-24^{\circ} \mathrm{C}$, remaining mostly close to $22^{\circ} \mathrm{C}$ during the day. Worms properly burrowed and stayed in the mixtures throughout the trial. The vermicomposting lasted for 56 days until the product appeared thoroughly processed. After extracting the worms, mixes were left for additional 14 days to ensure maturity. Throughout the experiment, the samples were collected in regular intervals to analyze the change of $\mathrm{pH}, \mathrm{C}$ and $\mathrm{N}$. In order to check the final mass of worms, vermicompost was spread on plastic trays and all worms, both mature and immature, were separated manually. The worms were then washed by briefly submerging in clean water and dried on paper towels before weighting.

\section{Measurement of $\mathrm{pH}$}

The $\mathrm{pH}$ was measured using the method according to ISO 10390:2005. Throughout the trial, fresh $2 \mathrm{~g}$ samples were taken on day 1, 28 and 70 and mixed with $20 \mathrm{~cm}^{3}$ of water or $1 \mathrm{M} \mathrm{KCl} \mathrm{solu-}$ tion. The resulting mixtures were left for the night and measured the next morning using a $\mathrm{pH}$ meter (Cole Parmer mod no. 59002-00).

\section{Total nitrogen and carbon measurement}

The samples were taken on day $0,14,28$ and 56 and air dried at room temperature. Nitrogen was measured with Kjeldahl method, according to PN-ISO 11261:2002 using a steam destilation apparatus (Buchi). Carbon was measured using multi N/C 2100 (Analytik Jena) with an attachment for measuring solids (HT 1300, Analytik Jena) according to the manufacturer's instructions.

\section{Maturity of vermicompost}

The first factor to assess the maturity of the vermicompost was the appearance and the smell of product. Rich dark color and no or earthy smell suggested the process is coming to an end. In the eighth week of the experiment trials containing biochar appeared thoroughly processed, so decision was made to remove the worms from all the trials and leave the mixtures for additional

Table 1. Amounts of substrates utilized to prepare trials in this study

\begin{tabular}{|c|c|c|c|c|c|c|}
\hline Name & Trial & Inoculum [g] & Sludge $[g]$ & $\begin{array}{c}\text { Coffee grounds } \\
{[\mathrm{g}]}\end{array}$ & Biochar [g] & Total mass $[\mathrm{g}]$ \\
\hline $\mathrm{OA}, \mathrm{OB}$ & Control - pure sludge & 0 & 500 & 0 & 0 & 500 \\
\hline $1 \mathrm{~A}, 1 \mathrm{~B}$ & Control - no worms & 100 & 0 & 400 & 0 & 500 \\
\hline $2 \mathrm{~A}, 2 \mathrm{~B}$ & $\begin{array}{l}\text { Control - sludge with no } \\
\text { worms }\end{array}$ & 100 & 400 & 0 & 0 & 500 \\
\hline $3 \mathrm{~A}, 3 \mathrm{~B}$ & Control & 100 & 0 & 400 & 0 & 500 \\
\hline $4 \mathrm{~A}, 4 \mathrm{~B}$ & Sludge - control & 100 & 400 & 0 & 0 & 500 \\
\hline $5 \mathrm{~A}, 5 \mathrm{~B}$ & $5 \%$ biochar & 100 & 400 & 0 & 26.32 & 526.32 \\
\hline $6 \mathrm{~A}, 6 \mathrm{~B}$ & $10 \%$ biochar & 100 & 400 & 0 & 55.55 & 555.55 \\
\hline $7 \mathrm{~A}, 7 \mathrm{~B}$ & $15 \%$ biochar & 100 & 400 & 0 & 88.23 & 588.23 \\
\hline
\end{tabular}


14 days. Then, a Micro-Oxymax apparatus (Columbus Instruments) was utilized to compare the samples on basis of the consumption of $\mathrm{O}_{2}$ and $\mathrm{CO}_{2}$ production. 3 grams of fresh sample was loaded into a glass bottle and attached to the device. Respirometry was measured for 4 days.

\section{Moisture content}

The samples were collected at the beginning of the experiment to assess the moisture content of the substrates. The employed method, according to PN-ISO 11465:1999, involved comparing the mass of a $5 \mathrm{~g}$ sample before and after drying in $105^{\circ} \mathrm{C}$.

\section{ICP - AES}

In order to analyze the elemental composition ICP-AES (Thermo) was utilized according to EPA Method 3051. The samples were collected on day 70 and air dried before mineralization by microwave digestion.

\section{RESULTS}

\section{Worm biomass}

The difference between the starting weight of worms $(10 \mathrm{~g})$ and the final weight is a key information about the conditions in each container. By starting with only mature worms and low stocking density, the expected outcome was for the worm biomass to increase, which would indicate a favorable environment to live and reproduce. The change in weight is represented on Figure 1.
The greatest loss of mass occurred in the trials $4 \mathrm{~A}$ and $4 \mathrm{~B}$, where between $6^{\text {th }}$ and $7^{\text {th }}$ week of experiment most worms were found dead, possibly due to the ammonia levels finally rising to toxic levels. Similarly high loss occurred in the trial $5 \mathrm{~B}$ but without visible dead specimens found. $3 \mathrm{~A}$ and $3 \mathrm{~B}$, utilized as control group containing no sludge, sustained a similar drop in the range of 2 grams, which indicates that the loss of weight may be attributed to lack of moisture near the end of the trial. A rise in $6 \mathrm{~A}$ and $6 \mathrm{~B}$ indicate that a $10 \%$ addition of biochar was sufficient to substitute for typically used bulking material. The 7A trial with $15 \%$ biochar had the greatest rise of 4 grams (and most young worms) but 7B sustained similar rise to $6 \mathrm{~A}$ and $6 \mathrm{~B}$, which suggests that the amounts of biochar larger than $10 \%$ may not be justifiable economically. Nonetheless, further testing is needed to define optimal amount of biochar - especially in the trials with substrates other than this specific kind of SS.

\section{$\mathrm{pH}$}

Usually in vermicomposting, the $\mathrm{pH}$ equalize during the trial to finally reach neutrality. Only in control, the $\mathrm{pH}$ values increased to finalize around $\mathrm{pH} 7.0$ (Table 2). In the rest of the trials, the $\mathrm{pH}$ was decreasing and finally reached the value as low as 4.65 in 5B. In other trials with biochar, the $\mathrm{pH}$ ranged from 5.08 to 5.86 . Overall, the $\mathrm{pH}$ values suggest that the products of decomposition of this particular substrate during vermicomposting are slightly acidic and accumulation of those compounds possibly led to toxic effects on worms in trials 4A, 4B and 5B. Initial addition of biochar had its effect on $\mathrm{pH}$ too as the initial values in trials $5 \mathrm{~A}$ to $7 \mathrm{~B}$ were increasingly higher than in $4 \mathrm{~A}$ and $4 \mathrm{~B}$.

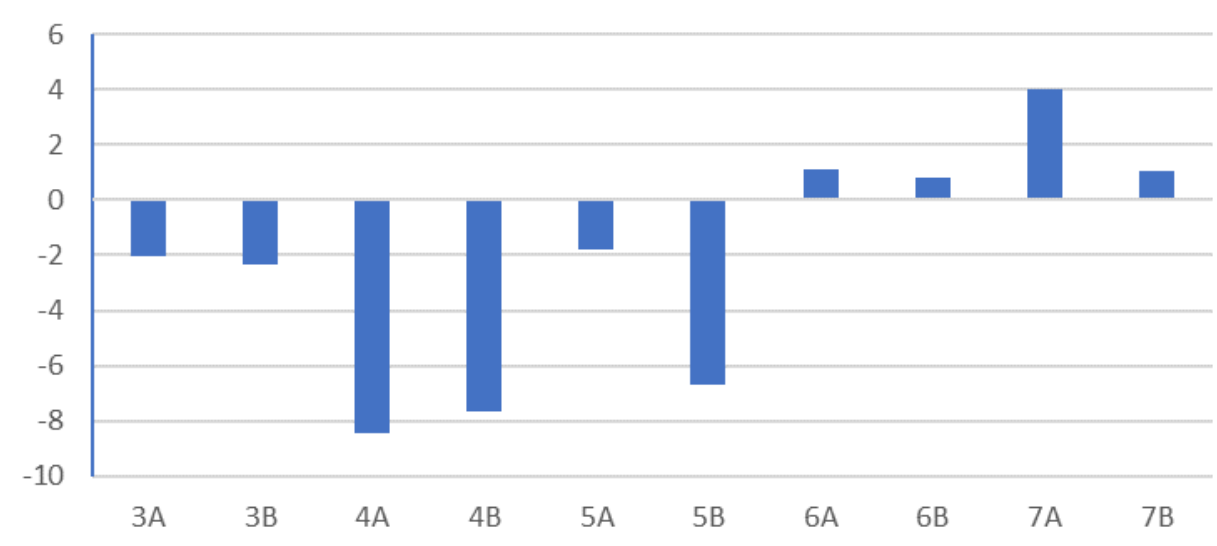

Figure 1. Final change of mass of worms in each trial. Only in trials containing $10 \%(6 \mathrm{~A}, 6 \mathrm{~B})$ and $15 \%(7 \mathrm{~A}, 7 \mathrm{~B})$ of biochar change was positive. Highest loss occurred in trials 4A, 4B and 5B 
Table 2. $\mathrm{pH}$ values of vermicompost, measured both in water and $1 \mathrm{M}$ solution of $\mathrm{KCl}$ on days 1, 28 and 70

\begin{tabular}{|c|c|c|c|c|c|c|}
\hline \multirow{2}{*}{ Day } & \multicolumn{3}{|c|}{$\mathrm{H}_{2} \mathrm{O}$} & \multicolumn{2}{|c|}{$\mathrm{KCl}$} \\
\hline & 1 & 28 & 70 & 1 & 28 & 70 \\
\hline OA & 7.59 & 7.16 & 5.51 & 6.85 & 6.86 & 6.47 \\
\hline OB & 7.59 & 7.58 & 6.14 & 6.85 & 7.24 & 5.06 \\
\hline 1A & 6.36 & 7.36 & 7.27 & 6.12 & 6.94 & 6.79 \\
\hline 1B & 6.37 & 7.20 & 7.02 & 5.93 & 6.85 & 6.76 \\
\hline 2A & 7.70 & 6.43 & 5.60 & 7.41 & 6.20 & 5.36 \\
\hline 2B & 7.68 & 6.43 & 5.78 & 7.42 & 6.41 & 5.79 \\
\hline 3A & 6.36 & 7.39 & 7.38 & 6.12 & 6.98 & 6.79 \\
\hline 3B & 6.37 & 6.98 & 7.18 & 5.93 & 6.78 & 6.83 \\
\hline $4 \mathrm{~A}$ & 7.70 & 6.19 & 5.38 & 7.41 & 6.06 & 5.26 \\
\hline 4B & 7.68 & 6.10 & 5.41 & 7.42 & 6.01 & 5.19 \\
\hline 5A & 7.95 & 5.21 & 5.08 & 7.62 & 6.22 & 4.72 \\
\hline 5B & 7.94 & 5.97 & 4.65 & 7.60 & 5.91 & 5.10 \\
\hline 6A & 8.10 & 6.33 & 5.15 & 7.74 & 6.47 & 5.18 \\
\hline 6B & 7.98 & 6.39 & 5.10 & 7.78 & 6.44 & 5.14 \\
\hline 7A & 8.22 & 6.65 & 5.86 & 8.01 & 6.67 & 5.87 \\
\hline 7B & 8.20 & 6.62 & 5.61 & 7.98 & 6.66 & 5.77 \\
\hline
\end{tabular}

\section{Maturity of vermicompost}

In order to define maturity, the product was first examined for a change in color, consistency and smell. Due to addition of biochar, the change of color was harder to notice in those trials but others were subject to a change of color from gray (natural color of used sewage sludge) to black. The smell changes as well - from slightly unpleasant, typically associated with sewage, to neutral or even slightly earthy - though trials with biochar again emitted no smell, possibly due to its sorption capabilities. However, the consistency changed visibly: in the case of control samples $(1 \mathrm{~A}, 1 \mathrm{~B}, 3 \mathrm{~A}, 3 \mathrm{~B})$ the initially packed material become loose and changed color from brown (due to coffee ground content) to black. The trials containing sludge but no biochar $(0 \mathrm{~A}$, $0 \mathrm{~B}, 2 \mathrm{~A}, 2 \mathrm{~B}, 4 \mathrm{~A}, 4 \mathrm{~B}$ ) were subject to change of color from gray to black, but the initial loose consistency changed to homogenous mass with visible signs of decomposition and developed mold. The trials with sludge and biochar (5A, $5 \mathrm{~B}, 6 \mathrm{~A}, 6 \mathrm{~B}, 7 \mathrm{~A}, 7 \mathrm{~B})$, initially containing noticeable grainy structure, become increasingly looser until the final form of coarse grains thoroughly processed by the worms in the $8^{\text {th }}$ week. In order to compare maturity with other mixes, vermicomposting was then stopped by removing the worms and the mixtures were left for additional two weeks to ensure stability.
In order to determine the final readiness, the samples were analyzed using micro-oxymax respirometer to check the intake of $\mathrm{O}_{2}$ and output of $\mathrm{CO}_{2}$ in the trials marked as A. Decrease in both indicates lower activity of microbes, which equals less organic compounds undergoing decomposition. The results of 4 day measurement are presented in Figures 2 and 3.

Both graphs indicate lowering respiration in all trials. Those with biochar (5A, 6A, 7A) had the lowest of all trials and throughout the analysis their levels stayed under $0.130 \mathrm{mg}_{\mathrm{O} 2} / \mathrm{h}$ and $0.070 \mathrm{mg}_{\mathrm{CO} 2} / \mathrm{h}$. Similar, but higher results were obtained in mixtures and A0, A2, A4 which indicates the sludge underwent slower decomposition without the worms. The highest levels were determined in the control trials $\mathrm{A} 1$ and $\mathrm{A} 3$, meaning the ones containing coffee grounds that are slower to decompose would require increased vermicomposting duration than those utilizing sewage sludge as substrate. Overall, the analysis suggests that the mixes containing biochar will mature faster and after 10 weeks the analyzed samples were determined stable and ready for use.

\section{$\mathrm{P}, \mathrm{K}$ and other minerals in obtained vermicompost}

In order to obtain quick estimate of mineral composition of products, ICP-AES was used. Raw results of triplicate measurement are 


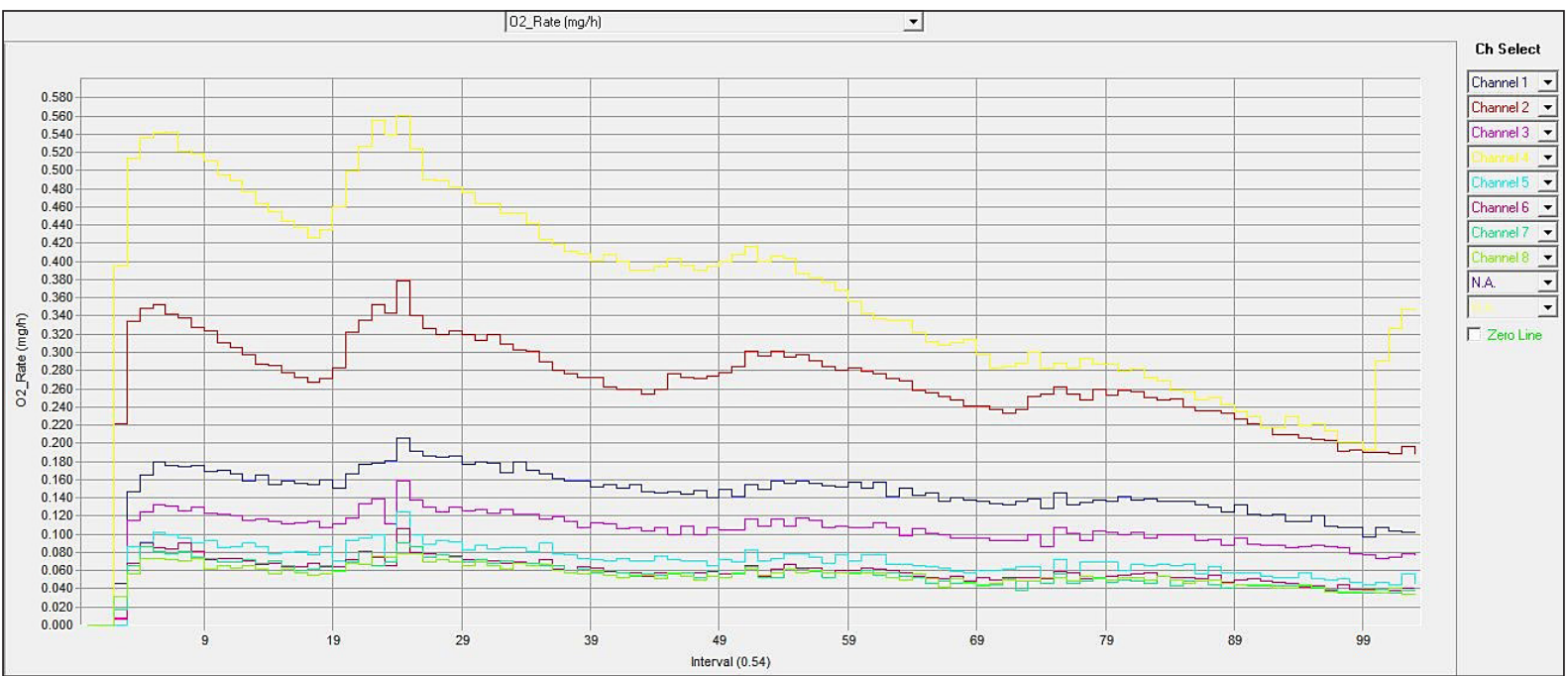

Figure 2. Rate of oxygen intake in $\mathrm{mg} / \mathrm{h}$ during 4 day trial. Consecutive channel numbers from 1 to 8 indicate trials from $\mathrm{A} 0$ to $\mathrm{A} 7$

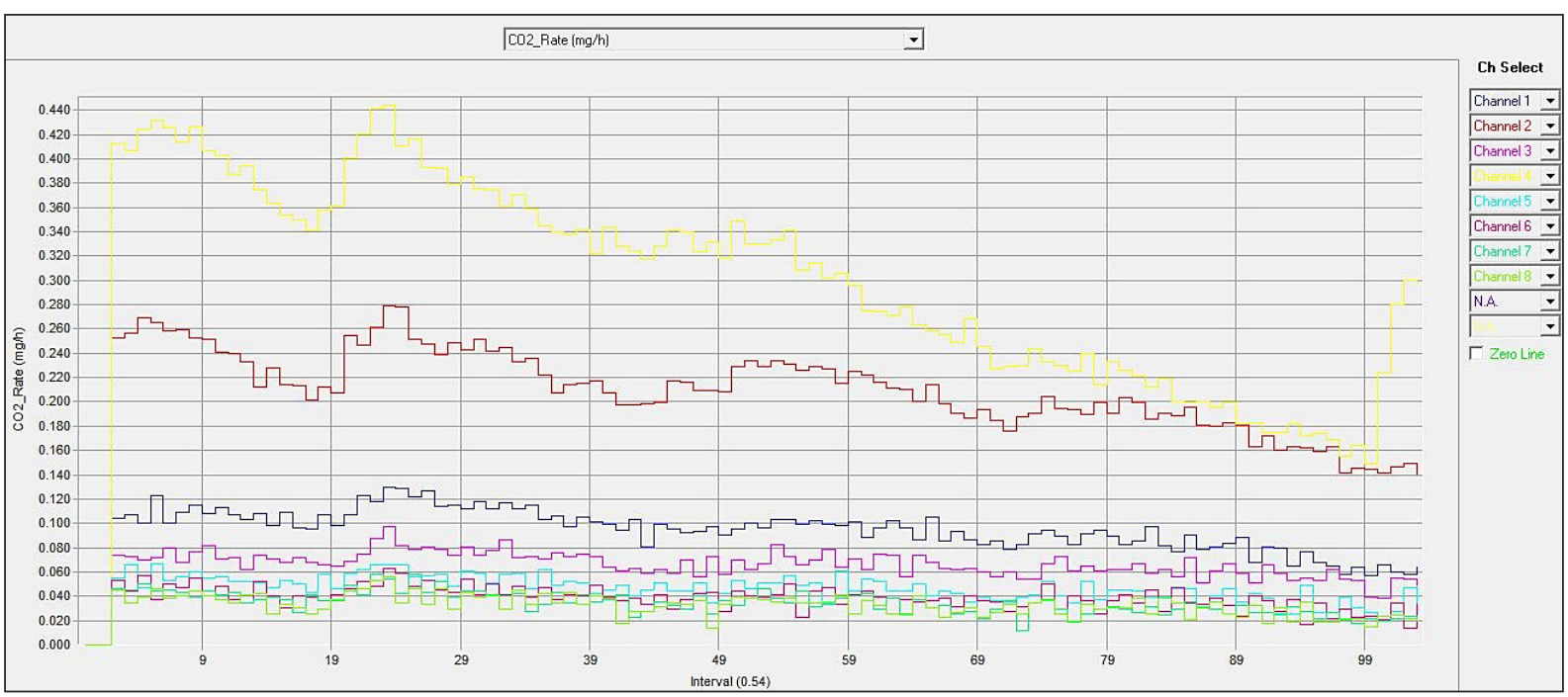

Figure 3. Rate of emmiting carbon dioxide in $\mathrm{mg} / \mathrm{h}$ during 4 day trial. Consecutive channel numbers from 1 to 8 indicate trials from $\mathrm{A} 0$ to $\mathrm{A} 7$

presented in Tables 3 and 4. Assay indicates that sewage sludge contains small amount of chromium, not found in any of the controls. The trials with biochar (5A to $7 \mathrm{~A}$ and $5 \mathrm{~B}$ to $7 \mathrm{~B}$ ) appear to contain lower concentration of elements due to replacement of some of its volume and weight with biochar. Figure 4 illustrates amounts of $\mathrm{K}$ and $\mathrm{P}$ in all trials with the highest amount in $2 \mathrm{~A}$ and $2 \mathrm{~B}$ and $4 \mathrm{~A}$ and $4 \mathrm{~B}$ and again decreasing concentration in the biochar amended trials.

\section{$\mathrm{C} / \mathrm{N}$ ratio}

For this particular experiment, the $\mathrm{C} / \mathrm{N}$ ratio suggests that the minimal value for successful process is around 15 (Figure 5). Trials 6A/B and $7 \mathrm{~A} / \mathrm{B}$ that exhibited positive worm biomass change started with $\mathrm{C} / \mathrm{N}$ ratio over 15 and it has risen during the trial. The control groups $1 \mathrm{~A} / \mathrm{B}$ and $3 \mathrm{~A} / \mathrm{B}$ also started above 15 but the ratio lowered during the trial and it is connected to the fact that biochar introduces carbon that does not break up quickly in the vermicomposting environment.

\section{CONCLUSIONS}

1. This simple pilot study confirms that in the case of vermicomposting of sewage sludge, bulking materials can be successfully replaced 
Table 3. Concentrations of selected elements as ICP-AES analysis in samples 0A through $7 \mathrm{~A}$. Results as mg/kg of dry sample. BT = below treshold

\begin{tabular}{|c|c|c|c|c|c|c|c|c|}
\hline & $\mathrm{OA}$ & $1 \mathrm{~A}$ & $2 \mathrm{~A}$ & $3 \mathrm{~A}$ & $4 \mathrm{~A}$ & $5 \mathrm{~A}$ & $6 \mathrm{~A}$ & $7 \mathrm{~A}$ \\
\hline $\mathrm{Al}$ & 35.74 & 32.37 & 54.21 & 44.39 & 49.31 & 34.91 & 29.23 & 21.76 \\
\hline $\mathrm{Ca}$ & 1282.23 & 1506.98 & 2181.48 & 1764.73 & 1925.63 & 1530.75 & 1315.76 & 1134.18 \\
\hline $\mathrm{Cd}$ & $\mathrm{BT}$ & $\mathrm{BT}$ & $\mathrm{BT}$ & $\mathrm{BT}$ & $\mathrm{BT}$ & $\mathrm{BT}$ & $\mathrm{BT}$ & $\mathrm{BT}$ \\
\hline $\mathrm{Co}$ & $\mathrm{BT}$ & $\mathrm{BT}$ & $\mathrm{BT}$ & $\mathrm{BT}$ & $\mathrm{BT}$ & $\mathrm{BT}$ & $\mathrm{BT}$ & $\mathrm{BT}$ \\
\hline $\mathrm{Cr}$ & 0.55 & $\mathrm{BT}$ & 0.15 & $\mathrm{BT}$ & 0.27 & 0.70 & 0.97 & 1.24 \\
\hline $\mathrm{Fe}$ & 76.88 & 57.64 & 120.59 & 87.22 & 118.22 & 107.22 & 95.01 & 87.43 \\
\hline $\mathrm{K}$ & 490.81 & 761.39 & 855.19 & 789.73 & 812.77 & 669.49 & 533.22 & 459.56 \\
\hline $\mathrm{Mg}$ & 271.65 & 158.61 & 269.47 & 194.30 & 266.66 & 219.58 & 182.66 & 161.68 \\
\hline $\mathrm{Mn}$ & 3.54 & 17.37 & 8.09 & 18.55 & 6.77 & 10.23 & 14.08 & 14.95 \\
\hline $\mathrm{Na}$ & 124.47 & 36.35 & 89.18 & 25.66 & 88.52 & 70.54 & 49.24 & 42.41 \\
\hline $\mathrm{P}$ & 406.65 & 161.05 & 470.29 & 176.68 & 415.56 & 302.57 & 253.55 & 203.58 \\
\hline $\mathrm{Pb}$ & $\mathrm{BT}$ & $\mathrm{BT}$ & $\mathrm{BT}$ & $\mathrm{BT}$ & $\mathrm{BT}$ & $\mathrm{BT}$ & $\mathrm{BT}$ & $\mathrm{BT}$ \\
\hline $\mathrm{Sr}$ & 0.58 & $\mathrm{BT}$ & 0.52 & $\mathrm{BT}$ & 0.35 & 0.44 & 0.21 & 0.08 \\
\hline $\mathrm{Zn}$ & 7.71 & 4.19 & 5.67 & 2.30 & 5.47 & 5.09 & 4.78 & 4.20 \\
\hline
\end{tabular}

Table 4. Concentrations of selected elements as ICP-AES analysis in samples 0B through 7B. Results as mg/kg of dry sample. BT = below threshold

\begin{tabular}{|c|c|c|c|c|c|c|c|c|}
\hline & OB & $1 \mathrm{~B}$ & $2 \mathrm{~B}$ & $3 \mathrm{~B}$ & $4 \mathrm{~B}$ & $5 \mathrm{~B}$ & $6 \mathrm{~B}$ & $7 \mathrm{~B}$ \\
\hline $\mathrm{Al}$ & 35.88 & 22.54 & 49.33 & 27.49 & 53.77 & 38.66 & 32.48 & 25.78 \\
\hline $\mathrm{Ca}$ & 1258.41 & 1394.49 & 1991.49 & 1801.37 & 1950.62 & 1515.09 & 1404.03 & 1275.65 \\
\hline $\mathrm{Cd}$ & $\mathrm{BT}$ & $\mathrm{BT}$ & $\mathrm{BT}$ & $\mathrm{BT}$ & $\mathrm{BT}$ & $\mathrm{BT}$ & $\mathrm{BT}$ & $\mathrm{BT}$ \\
\hline $\mathrm{Co}$ & $\mathrm{BT}$ & $\mathrm{BT}$ & $\mathrm{BT}$ & $\mathrm{BT}$ & $\mathrm{BT}$ & $\mathrm{BT}$ & $\mathrm{BT}$ & $\mathrm{BT}$ \\
\hline $\mathrm{Cr}$ & 0.75 & $\mathrm{BT}$ & 0.15 & $\mathrm{BT}$ & 0.34 & 0.43 & 0.96 & 1.09 \\
\hline $\mathrm{Fe}$ & 94.18 & 43.33 & 123.17 & 51.28 & 133.18 & 107.23 & 104.59 & 134.01 \\
\hline $\mathrm{K}$ & 542.25 & 578.33 & 753.28 & 703.83 & 770.37 & 620.22 & 577.95 & 494.32 \\
\hline $\mathrm{Mg}$ & 306.51 & 144.53 & 261.91 & 174.50 & 285.05 & 219.34 & 204.29 & 177.56 \\
\hline $\mathrm{Mn}$ & 2.86 & 14.42 & 8.35 & 19.46 & 6.68 & 10.15 & 14.29 & 15.53 \\
\hline $\mathrm{Na}$ & 117.81 & 14.53 & 82.13 & 16.84 & 82.95 & 62.87 & 52.47 & 42.21 \\
\hline $\mathrm{P}$ & 346.97 & 148.97 & 413.78 & 161.68 & 395.79 & 274.25 & 247.55 & 213.55 \\
\hline $\mathrm{Pb}$ & $\mathrm{BT}$ & $\mathrm{BT}$ & $\mathrm{BT}$ & $\mathrm{BT}$ & $\mathrm{BT}$ & $\mathrm{BT}$ & $\mathrm{BT}$ & $\mathrm{BT}$ \\
\hline $\mathrm{Sr}$ & 0.66 & $\mathrm{BT}$ & 0.33 & $\mathrm{BT}$ & 0.36 & 0.38 & 0.24 & 0.14 \\
\hline $\mathrm{Zn}$ & 6.54 & 1.09 & 5.56 & 1.54 & 5.95 & 5.25 & 5.22 & 4.74 \\
\hline
\end{tabular}

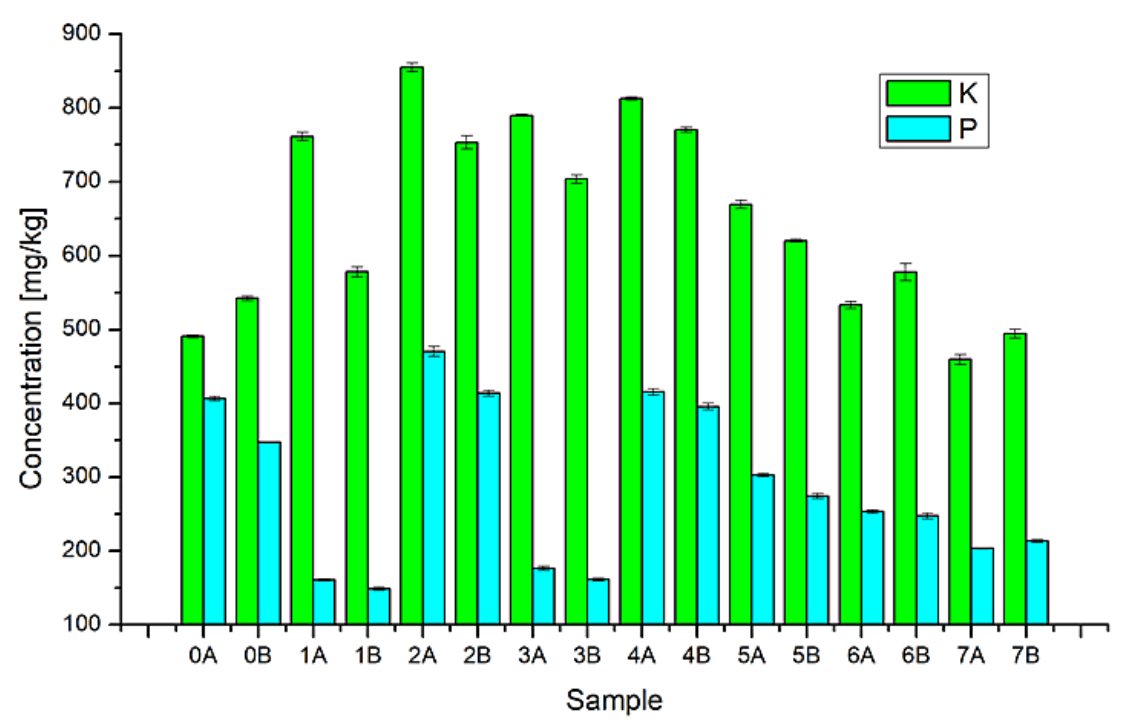

Figure 4. Comparison of $\mathrm{K}$ and $\mathrm{P}$ concentration in all trials as $\mathrm{mg} / \mathrm{kg}$ of dry mass 


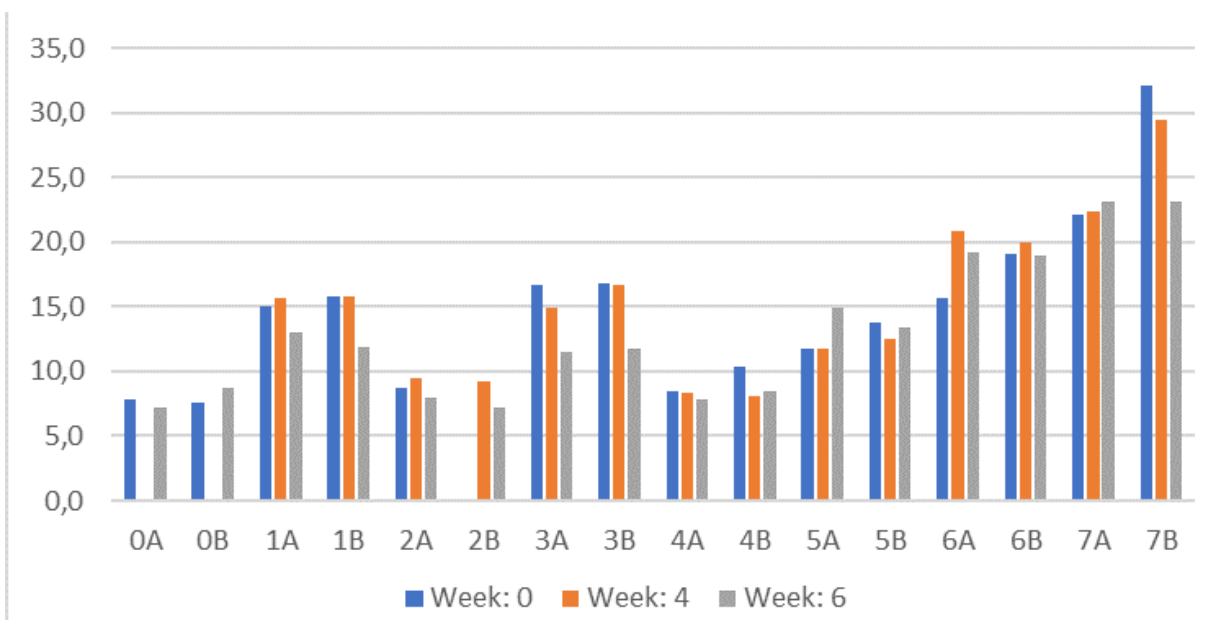

Figure 5. Starting $\mathrm{C} / \mathrm{N}$ ratio and it's change after 4th and 6 th week

with a sufficient dose of biochar. The doses of $10 \%$ and higher content had positive effects both on the worm population and the qualities of the product. However, it is unknown if the obtained results apply to other substrates that can be used to produce such vermicompost; thus, tests with other kinds of sewage sludge will be needed to determine a universal dose. Due to small scale of experiment, it is inconclusive how the effectiveness changes with higher amount of biochar. However, it is likely that there is an optimal dose that would work for most sewage sludge types depending on their initial moisture content. It is also necessary to develop new testing techniques as addition of biochar severely impact testing procedures, e.g. TOC assay.

2. During the initial review of research, only a few cases of biochar use as bulking agent were found. In 2010, a research of Dias et al. biochar was compared with coffee husk and sawdust as a bulking material in conventional composting of poultry manure. The reported benefits of use of biochar include the reduction of odor emissions and the lowest loss of nitrogen out of all tested mixtures [Dias et al. 2010].

3. Earlier research of Hua et al. in 2009, also confirms the positive effects on nitrogen conservation. The research involved conventional composting of sewage sludge with biochar. The change in the mobility of $\mathrm{Cu}$ and $\mathrm{Zn}$, which was noticeably lowered in case of biochar amended mixtures, was tested as well. Both effects were linked to the biochar adsorption capabilities in the case of nitrogen specifically pointed out as binding of ammonia [Hua et al. 2009]. This hints at a possible use of vermicompost with biochar as amendment for the topsoil polluted by heavy metals and other substances that may be scrubbed by biochar and thus stopped from seeping into lower layers. This effect may be useful in phytoremediation and was explored in the past [Hernandez-Soriano et al. 2016; Wang et al. 2018].

4. Mixes of mature vermicompost amended with biochar were studied to a greater extent. In 2014, the research by Doan et al. reported overall positive effect of amendments on the growth of maize. The loss of nitrogen was again mentioned to decrease in the cases of biochar addition, this time measured in soil. Additions of biochar and vermicompost were also found to decrease the soil erosion and increase resistance of plants to water shortages [Doan et al. 2015].

5. There are more benefits of biochar usage in organic fertilizer production than those already mentioned. Majority of the carbon accumulated during growth of biomass is preserved during pyrolysis and changes to mostly inert form [Hernandez-Soriano et al. 2016]. Not only does biochar have a beneficial effect on soil quality, it can be also used to sequester carbon and thus may be a part of strategy to offset the carbon footprint [Matovic 2011]. The gases produced during the pyrolysis of biomass can be used to generate energy and so, it constitutes an effective strategy to deal with excess biowaste as an alternative to its direct combustion to produce electricity or heat. The high cost of biochar that makes some of its uses uneconomical at present, would no 
longer apply as it would become a cheap and abundant byproduct for use in the environmental and industrial applications [McHenry 2009; Schmidt and Wilson 2012].

6. In our opinion, the biochar will become an important part of the future sustainable agriculture and environmental engineering. Combined with fast and effective process of biowaste vermicomposting, it constitutes a promising strategy for the production of a fertilizer useful for organic farming. The proposed product may be used to improve the soil quality, both in the context of crop production and counteracting the effects of soil degradation.

\section{Acknowledgements}

Research funded from internal grant BS/PB -401-304/11.

Publication supported by the Polish Ministry of Science and Higher Education as a part of the program of activities disseminating science from the project „Organization of the First International Science Conference - Ecological and Environmental Engineering", 26-29 June 2018, Kraków.

\section{REFERENCES}

1. Day, A.D., and Ludeke, K.L. 1993. Plant Nutrients in Sewage Sludge. In Plant Nutrients in Desert Environments, J. L. Cloudsley-Thompson, A. D. Day and K. L. Ludeke, Eds. Springer Berlin Heidelberg, Berlin, Heidelberg, 75-82.

2. Dias, B.O., Silva, C.A., Higashikawa, F.S., Roig, A., and Sánchez-Monedero, M.A. 2010. Use of biochar as bulking agent for the composting of poultry manure. Effect on organic matter degradation and humification. Bioresource technology 101, 4, 1239-1246.

3. Doan, T.T., Bouvier, C., Bettarel, Y., Bouvier, T., Henry-des-Tureaux, T., Janeau, J.L., Lamballe, P., van Nguyen, B., and Jouquet, P. 2014. Influence of buffalo manure, compost, vermicompost and biochar amendments on bacterial and viral communities in soil and adjacent aquatic systems. Applied Soil Ecology 73, 78-86.

4. Doan, T.T., Henry-des-Tureaux, T., Rumpel, C., Janeau, J.-L., and Jouquet, P. 2015. Impact of compost, vermicompost and biochar on soil fertility, maize yield and soil erosion in Northern Vietnam. A three year mesocosm experiment. The Science of the total environment 514, 147-154.
5. Hernandez-Soriano, M.C., Kerré, B., Kopittke, P.M., Horemans, B., and Smolders, E. 2016. Biochar affects carbon composition and stability in soil. A combined spectroscopy-microscopy study. Scientific Reports 6, 25127 EP -.

6. Hua, L., Wu, W., Liu, Y., McBride, M.B., and Chen, Y. 2009. Reduction of nitrogen loss and $\mathrm{Cu}$ and $\mathrm{Zn}$ mobility during sludge composting with bamboo charcoal amendment. Environmental science and pollution research international 16, 1, 1-9.

7. Kijo-Kleczkowska, A., Otwinowski, H., and Środa, K. 2012. Properties and production of sewage sludge in Poland with reference to the methods of neutralizing. Archives of Journal of Waste Management and Environmental Protection 2012, 4, 59-78.

8. Leila, S., Mhamed, M., Hermann, H., Mykola, K., Oliver, W., Christin, M., Elena, O., and Nadia, B. 2017. Fertilization value ofmunicipal sewage sludge for Eucalyptus camaldulensis plants. Biotechnology reports (Amsterdam, Netherlands) 13, 8-12.

9. Ludibeth, S.-M., Marina, I.-E., and Vicenta, E.M. 2012. Vermicomposting of Sewage Sludge. Earthworm Population and Agronomic Advantages. Compost Science \& Utilization 20, 1, 11-17.

10. Malińska, K., Zabochnicka-Świątek, M., Cáceres, R., and Marfà, O. 2016. The effect of precomposted sewage sludge mixture amended with biochar on the growth and reproduction of Eisenia fetida during laboratory vermicomposting. Ecological Engineering 90, 35-41.

11. Matovic, D. 2011. Biochar as a viable carbon sequestration option. Global and Canadian perspective. Energy 36, 4, 2011-2016.

12. McHenry, M.P. 2009. Agricultural bio-char production, renewable energy generation and farm carbon sequestration in Western Australia. Certainty, uncertainty and risk. Agriculture, Ecosystems \& Environment 129, 1-3, 1-7.

13. Medyńska-Juraszek, A. 2016. Biochar as a soil amendment. Soil Science Annual 67, 3, 626.

14. Meller Harel, Y., Kolton, M., Elad, Y., Rav-David, D., Cytryn, E., Borenshtein, M., Shulchani, R., and Graber, E. 2012. Biochar impact on plant development and disease resistance in pot trials. IOBC WPRS Bull. 2012, 78, 141-147.

15. Mininni, G., and Santori, M. 1987. Problems and perspectives of sludge utilization in agriculture. Agriculture, Ecosystems \& Environment 18, 4, 291-311.

16. Mu, J., Li, X., Jiao, J., Ji, G., Wu, J., Hu, F., and Li, H. 2017. Biocontrol potential of vermicompost through antifungal volatiles produced by indigenous bacteria. Biological Control 112, 49-54.

17. Munroe, G. 2007. Manual of on-farm vermicomposting and vermiculture. Organic Agriculture Centre of Canada 39, 40. 
18. Raheem, A., Sikarwar, V.S., He, J., Dastyar, W., Dionysiou, D.D., Wang, W., and Zhao, M. 2018. Opportunities and challenges in sustainable treatment and resource reuse of sewage sludge. A review. Chemical Engineering Journal 337, 616-641.

19. Schmidt, H.-P., and Wilson, K. 2012. 55 uses of biochar. Ithaka J 1, 286-289.

20. Suthar, S. 2009. Vermicomposting of vegetable-market solid waste using Eisenia fetida. Impact of bulking material on earthworm growth and decomposition rate. Ecological Engineering 35, 5, 914-920.
21. Vigueros, L.C., and Ramírez Camperos, E. 2002. Vermicomposting of sewage sludge. A new technology for Mexico. Water science and technology : a journal of the International Association on Water Pollution Research 46, 10, 153-158.

22. Wang, Y., Xu, Y., Li, D., Tang, B., Man, S., Jia, Y., and Xu, H. 2018. Vermicompost and biochar as bio-conditioners to immobilize heavy metal and improve soil fertility on cadmium contaminated soil under acid rain stress. The Science of the total environment 621, 1057-1065. 